Abstracta Iranica Abstracta Iranica

Revue bibliographique pour le domaine irano-aryen

Volume 27 | 2006

Comptes rendus des publications de 2004

\title{
"A recently acquired incense burner in the Khalili Collection ». Muqarnas, XXI (2004), pp. 215-218.
}

\section{Rocco Rante}

\section{(2) OpenEdition}

1 Journals

Édition électronique

URL : http://journals.openedition.org/abstractairanica/6131

DOI : 10.4000/abstractairanica.6131

ISSN : 1961-960X

\section{Éditeur :}

CNRS (UMR 7528 Mondes iraniens et indiens), Éditions de l'IFRI

\section{Édition imprimée}

Date de publication : 15 mai 2006

ISSN : 0240-8910

\section{Référence électronique}

Rocco Rante, « «A recently acquired incense burner in the Khalili Collection ». Muqarnas, XXI (2004), pp. 215-218. 》, Abstracta Iranica [En ligne], Volume 27 | 2006, document 244, mis en ligne le 02 janvier 2007, consulté le 25 septembre 2020. URL : http://journals.openedition.org/abstractairanica/6131 ; DOI : https://doi.org/10.4000/abstractairanica.6131

Ce document a été généré automatiquement le 25 septembre 2020.

Tous droits réservés 


\title{
«A recently acquired incense burner in the Khalili Collection ". Muqarnas, XXI (2004), pp. 215-218.
}

\author{
Rocco Rante
}

Cette acquisition est un encensoir en forme de lion dont la facture, finement analysée par l'A., est particulièrement élégante. Sa décoration est surprenante car elle présente, selon K.N., des références épigraphiques avec les sceaux shi'ites. Les détails du décor, comparés à d'autres encensoirs, amènent l'A à proposer une provenance Khurassanienne d'époque seljukide. L'absence des noms du propriétaire et de l'artisan dans l'inscription indiquerait une production massive et couvrant une période d'au moins deux ou trois générations.

\section{INDEX}

Thèmes : 5.1. Monde iranophone

\section{AUTEURS}

ROCCO RANTE

IFRI - Téhéran 